GRAŻYNA SZELĄGOWSKA

Uniwersytet Warszawski

\title{
O ZWYCIĘSTWIE KULTURY NAD POLITYKĄ. JAK ODWIECZNI WROGOWIE STWORZYLI SUWERENNE PAŃSTWA I WSPÓŁCZESNĄ WSPÓLNOTĘ NORDYCKĄ
}

Region nordycki postrzegany jest współcześnie jako wspólnota. Jego mieszkańcy używają terminu Norden (dosł. Północ), który jest adekwatnym określeniem regionu geograficznego obejmującego nie tylko Półwysep Skandynawski, ale także Islandię, Wyspy Owcze oraz Finlandię. Jest także pewnym pojęciem, za którym kryją się ukształtowane historycznie czynniki, jak oparta na wspólnej wczesnośredniowiecznej podstawie bliskość kulturowa. Wspólne były wierzenia, język, sagi, kultura życia codziennego i społecznego, dążenia do poznawania świata i zdobywania nowych terytoriów, a nawet podobny sposób przyjmowania chrześcijaństwa. Zwraca uwagę ówczesne podobieństwo pokrewnych języków skandynawskich (poza fińskim), a sięgając do czasów nowożytnych wyznanie ewangelicko-augsburskie (z pewnymi drobnymi różnicami) i tradycje wspólnot państwowych. Norden to także specyficzny dla tego regionu system społeczny, ekonomiczny i polityczny, a także odróżniająca się od reszty Europy mentalność. Gdy zaś porównać dziewiętnastowieczne procesy modernizacyjne, okaże się, że we wszystkich częściach regionu nordyckiego przebiegały one podobnie, na zbliżonej podstawie społecznej i ekonomicznej. A niemal identyczne struktury i funkcjonowanie Kościołów luterańskich w XIX w. wpłynęły na powstanie i rozwój w całym regionie masowego ruchu kaznodziejskiego i wolnych Kościołów.

Jednak gdy przyjrzeć się dziejom regionu, okaże się, że aż do początków XX w. państwa nordyckie bywały ze sobą przeważnie skłócone i jeśli nie dążyły do wzajemnego podporządkowania, to najchętniej zamieniłyby cieśniny duńskie w nieprzebyte wąwozy. Począwszy od epoki 
wikińskiej Skandynawowie zmagali się ze sobą o hegemonię w regionie. W toku tych walk stopniowo wykształcały się odrębne języki nordyckie, ale przede wszystkim niezależne i silne monarchie. W 1397 r. połączyła je unia kalmarska. Monarchie, które ją powołały, to Dania, Norwegia i Szwecja. W unii znalazły się także Grenlandia, Islandia i Wyspy Owcze (norweskie), Finlandia (szwedzka) oraz w okresie późnego średniowiecza księstwa Szlezwik i Holsztyn (duńskie). Kusząca wydaje się refleksja, że stanowiła ona pewien prototyp współczesnej wspólnoty nordyckiej. W rzeczywistości jednak był to - wbrew zawartym w traktacie kalmarskim zapisom o równości partnerów unijnych - układ zdominowany przez Danię i wyraz jej dążeń do hegemonii w regionie nordyckim. 0 ile Norwegia, osłabiona pod każdym względem „czarną śmiercią”, stanowiła w systemie kalmarskim raczej przedmiot niż podmiot polityki, to z pewnością nie można tego było powiedzieć o szybko rozwijającej się Szwecji.

Szwecja praktycznie już od połowy XV w. usiłowała rozluźnić krępujące pęta unii kalmarskiej, na co kolejni duńscy monarchowie odpowiadali upartą koronacją na królów Szwecji i zwalczaniem antyduńskich powstań chłopskich oraz buntów możnowładczych. Apogeum walki przypadło na rok 1520. Duński król Chrystian II wywołał zwycięską wojnę ze Szwecją i koronował się na jej króla, po czym w sposób bulwersujący już współczesnych pozbył się opozycji magnackiej: w trakcie koronacji w Sztokholmie wymordował blisko stu zaproszonych na uroczystość i należących do szwedzkiej elity magnatów. „Krwawa łaźnia” zmobilizowała wszystkie stany społeczeństwa i wyniosła na tron Gustawa Erikssona, założyciela dynastii Wazów. Wykopała także przepaść między Danią i Szwecją, inicjując trwające trzy stulecia nieustanne wojny o dominium Maris Baltici. To wówczas narodziło się po obu stronach Sundu pojęcie „wroga dziedzicznego" (arvefiende), żywotne jeszcze na początku XIX w.

W latach reformacji biskup Trondheim Olav Engelbrektsson usiłował wykorzystać opór Norwegów przeciwko narzucanemu przez Danię luteranizmowi i podjął próbę zdobycia niezależności. Nie tylko się nie powiodła, ale nawet pogorszyła status Norwegii wobec Danii. Z określonego w traktacie kalmarskim podmiotu równego Danii, kraj ten został sprowadzony w 1536 r. do roli podporządkowanej Kopenhadze prowincji.

Rozpad unii kalmarskiej stworzył nowy układ geopolityczny w regionie nordyckim. Pojawiły się wówczas dwie monarchie: Dania-Norwegia wraz z Islandią, Wyspami Owczymi, Grenlandią i księstwami Szlezwik-Holsztyn w zachodniej części regionu, zaś po stronie wschodniej Szwecja ze ściśle zintegrowaną prowincją Finlandią. System dwu monarchii nordyckich przetrwał aż do początków XX w., choć wydarzenia epoki napoleońskiej - zawirowania dyplomatyczne, wojny oraz przemiany ustrojowe 
i terytorialne części regionu - nieco go przetasowały. W wyniku klęski w wojnie z Rosją w 1808 r. Szwecja bezpowrotnie utraciła prowincję fińską; w 1809 Finlandia jako Wielkie Księstwo została włączona do Imperium Rosyjskiego. Zaś dzięki dyplomatycznym umiejętnościom nowego szwedzkiego następcy tronu, założyciela nowej dynastii Bernadotte i późniejszego Karola XIV Jana, Szwecja zyskała poparcie mocarstw (zwłaszcza Rosji) dla rekompensaty w postaci przyłączenia Norwegii. W wyniku krótkiej wojny szwedzko-duńskiej i na mocy traktatu kilońskiego z 1814 r. Norwegia została oderwana od monarchii duńskiej i po ponad czterystu latach związek duńsko-norweski przestał istnieć.

Wydarzenia roku 1814, a zwłaszcza przypieczętowujący zmianę przynależności Norwegii traktat kiloński, stały się impulsem do walki narodowej Norwegów, którzy rozpoczęli trwającą kilka miesięcy nieudaną próbę wybicia się na niepodległość. Choć suwerenne państwo norweskie wówczas nie powstało, udało się im wywalczyć równorzędny status w szwedzko-norweskiej unii personalnej. Trwałą zdobyczą, która do dziś pozostaje dla Norwegów symbolem wolności, była uchwalona w toku walki liberalna konstytucja.

Dania zdołała zatrzymać wszystkie norweskie posiadłości atlantyckie, które Norwegia w posagu wniosła do unii kalmarskiej. Ostatecznie $\mathrm{w}$ regionie nadal istniały zaledwie dwie monarchie: na wschodzie szwedzko-norweska unia personalna, na zachodzie natomiast Dania z wszystkimi terytoriami zamorskimi, tj. Islandią, Wyspami Owczymi, Grenlandią oraz księstwami Szlezwik i Holsztyn. Powyższy układ geopolityczny przetrwał aż do XX w.

Kilka stuleci konfliktów i wojen wpłynęło na wykształcenie się w regionie nordyckim negatywnych stereotypów, wzajemnej wrogości i postawy „wroga odwiecznego”, izolacjonizmu i nacjonalizmów. Na początku XIX w., w chwili zakończenia wojen napoleońskich, pomiędzy wszystkimi krajami regionu utrzymywała się głęboka niechęć, a czasem wręcz nienawiść. Szwedzi pamiętali Danii sztokholmską „krwawą łaźnię” i niemal każdą próbę zbliżenia politycznego interpretowali jako chęć odtworzenia unii kalmarskiej. Norwegowie zaś wypominali jej 400 lat „niewoli” oraz sprzedanie, jak mawiano, Norwegii Szwedom.

Przezwyciężenie tych wszystkich uprzedzeń i przełamanie wzajemnej niechęci wynikało $\mathrm{z}$ wielu powodów i miało źródła w wielu procesach. Proponuję zwrócić uwagę na jedno zjawisko - na koncepcję tzw. skandynawizmu, czyli nowej nordyckiej wspólnoty. Idea wypłynęła ze strony duńskiej elity kulturalnej, która w odwołującym się do średniowiecznej historii i kultury (zwłaszcza sag i mitologii nordyckiej) zbliżeniu nordyckim widziała ratunek dla Danii - już nie mocarstwa, ale małego, słabego 
i żyjącego w poczuciu zagrożenia państwa. Przez całe XIX stulecie idea ewoluowała: od oświeceniowych w założeniu programów naukowej i literackiej współpracy, poprzez romantyczne koncepcje jedności pannarodowej, które usiłowali propagować studenci z Kopenhagi, z różnym skutkiem namawiając do zacieśniania więzów kolegów z Uppsali, Lund oraz Christianii (późniejszego Oslo), by wreszcie w drugiej połowie XIX w. zainteresować nordyckich monarchów.

Źródeł skandynawizmu szukać należy w XVIII w., w tradycjach duńskiego i szwedzkiego oświecenia. Ograniczał się on wówczas do postulatów rozwijania kontaktów naukowych i literackich w imię szerzenia oświaty i wiedzy o sąsiadach ${ }^{1}$. Powszechny postęp cywilizacyjny był w tym przypadku kryterium odrzucenia przez skandynawskich uczonych tezy o odwiecznym wrogu dziedzicznym, a wrogość wobec odmiennej nacji była po prostu sprzeczna z nakazami rozsądku. Skandynawizm ten ograniczał się do osobistych przyjaźni duńskich i szwedzkich intelektualistów, nie wychodząc poza krąg problematyki literackiej i naukowej (zwłaszcza historycznej), był jednak pierwszym przełamaniem swoistego tabu, jakim były stosunki Danii ze Szwecją ${ }^{2}$. Pierwszy krok do unionizmu nordyckiego (jak to przedstawia większość historyków skandynawskich), to bardzo ostrożne poznawanie się, tłumaczenia literatury duńskiej i szwedzkiej oraz edytorstwo.

Jak dużym obciążeniem były historyczne zaszłości, pokazują dzieje różnego rodzaju nieudanych inicjatyw wydawniczych, kierowanych przez Duńczyków w stronę szwedzkich uczonych i pisarzy. Głosy niechęci - i to $\mathrm{z}$ obu stron - dowodziły istnienia silnie zakorzenionych uprzedzeń do sąsiada i wynikających z nich podejrzeń o rzeczywiste, a niecne motywy działania. Kopenhascy uczeni wskazywali na skutki uboczne zbliżenia skandynawskiego w postaci ,amalgamacji” obu kultur i zanikania ich odrębności np. językowych ${ }^{3}$. Przedstawiciele szwedzkiej elity kulturalnej, odrzucając ideę współpracy, przywoływali (dwieście lat po „krwawej łaźni” sztokholmskiej!) czasy unii kalmarskiej.

Idea skandynawizmu przetrwała w postaci prywatnych znajomości i kontaktów między uczonymi i artystami. Ich utrzymanie miało o tyle głębszy sens, że po 1814 r. nie tylko wszystkie stosunki oficjalne między

${ }^{1}$ J. Clausen, Skandinavismen historisk fremstillet, København 1900.

2 Np. kontakty historyków, Szweda Svena Lagerbringa (1707-1787) i Duńczyka Jacoba Langebeka (1710-1775), które od wymiany pamfletów przekształciły się w korzystną dla obu współpracą naukową. Podobny wydźwięk miała przyjaźń rzeźbiarza szwedzkiego Johana Tobiasa Sergela (1740-1814) i malarza duńskiego Nicolaia Abrahama Abildgaarda (1743-1809).

3 „Københavns Universitets Journal”, København 1797, seria wyd. 5, t. 4, s. 156 n. 
Danią a Szwecją praktycznie zamarły, ale nawet owe nieoficjalne usiłowano powstrzymać drogą restrykcji i administracyjnych przeszkód. Mając na względzie utrzymanie dobrych stosunków z Rosją, Karol Jan dążył do ograniczenia wszelkich kontaktów obywateli szwedzkich z Danią, za którą nadal ciągnęła się opinia niefortunnej sojuszniczki Napoleona. Uczonym władze odmawiały wydania paszportu bez podania przyczyny, innych poddawano ścisłej inwigilacji ${ }^{4}$. Duńskie władze nie pozostawały dłużne. W 1816 r. wydano zakaz podróżowania szwedzkimi statkami, co wobec znacznie droższej komunikacji duńskiej skutecznie ograniczyło na pewien okres wszelkie kontakty ${ }^{5}$. Mimo to podróże naukowe i literackie, a także prywatne, nie ustawały, a nawet powoli przekształcały się w modę. Taki charakter nosiły bez wątpienia pielgrzymki szwedzkich miłośników poezji do domu wybitnego duńskiego poety romantycznego Adama Oehlenschlägera. Symbolicznym dla późniejszych apologetów skandynawizmu wydarzeniem stała się w czerwcu 1829 r. promocja tego twórcy w katedrze w Lund na króla poezji nordyckiej. „Minął czas rozdzielenia i niechże nigdy nie powróci w wolnym, nieskończonym świecie ducha" - z tymi słowami wybitny szwedzki poeta Esaias Tegnér nałożył poecie duńskiemu na głowę wieniec laurowy ${ }^{6}$.

Uczestnicy tych spotkań tworzyli wraz z duńską elitą intelektualną grupę, która w naturalny sposób realizowała postulaty skandynawizmu, rozumianego jako wzajemne poznawanie i kształtowanie nowego w historii kultury Skandynawii poczucia jedności nordyckiej ${ }^{7}$. Owocem tego praktycznego współdziałania było m.in. promowane przez duńskiego historyka i krytyka literackiego Christiana Molbecha czasopismo, podejmujące historyczną i artystyczną tematykę skandynawską ${ }^{8}$.

Narodziny nowej nauki, archeologii, która miała rzucić światło na najstarsze dzieje Skandynawii, to rezultat współpracy duńskich i szwedzkich badaczy przeszłości, Duńczyka Christiana J. Thomsena, twórcy trójpodziału czasów prehistorycznych na epokę kamienia, brązu i żelaza, oraz Szweda Brora Emila Hildebranda. Dla przełamywania barier być może większe znaczenie miały kontakty towarzyskie. Recytowanie wierszy

${ }^{4}$ V. Andersen, Et livs poesi, Adam Oehlenschläger, t. 2, København 1899-1900, s. 232.

${ }^{5}$ List Ch. Molbecha do L. Hammarskjölda, 30 V 1816, Christian Molbech. Brevveksling med svenske forfattere og videnskabsmaend, oprac. M. Borup, t. 1, København 1956, s. 143.

6 „Ude og Hjemmet”, København, 19 I 1879.

7 Patrz liczna korespondencja: Udvalg af breve fra maend og quinder skrevne gjennem en lang raekke aar til Peder Hjort, t. 1-2, oprac. P. Hjort, København 1867-1869, t. 2, s. 336.

8 „Nordisk Tidsskrift for Historie, Litteratur og Kunst” (1827-1836), patrz także: korespondencja na ten temat Molbecha z pisarzami i historykami szwedzkimi, w: Ch. Molbech, Breveksling, t. 1, s. 32, 37, t. 2, s. 16-17, 72-73. 
o tematyce skandynawskiej stanowiło urozmaicenie i swego rodzaju przerywnik spotkań przy alkoholu, od którego Skandynawowie bynajmniej nie stronili.

Dla przemiany prostego postulatu poznawania literatury krajów sąsiednich w koncepcję unionizmu o wymiarze panskandynawskim szczególne znaczenie miał nordycki romantyzm, który skupiał się przede wszystkim na zagadnieniach filozoficznych i historycznych.

Romantyczny zwrot i zagłębienie się w dziejach Skandynawia zawdzięcza norweskiemu filozofowi i przyrodnikowi Henrikowi Steffensowi. Jego osobiste kontakty z braćmi Schleglami, Schellingiem, Tieckiem, Novalisem, zapoznanie się z dziełami Herdera, Fichtego, ale także Kanta, Goethego i Schillera, zaowocowały cyklem wykładów w Kopenhadze na przełomie lat 1802 i 1803. Steffens uważał się za rzecznika niemieckiego idealizmu filozoficznego, który interpretował jako jedność i nieskończoną harmonię wszechrzeczy. Jednostki, jak mówił, pragną potwierdzić swą niezależność, lecz wszechogarniająca jedność walczy o ich organiczne połączenie w harmonijną całość. Za Kantem głosił, że historia jest dowodem przenikania wolności i konieczności. Widział w tym połączenie wolności jednostki i jej podporządkowania wyższym celom 9 .

Za jej czynnik jednoczący uważał, znów sięgając do koncepcji niemieckich klasyków idealizmu, wiecznego ducha (ideę), obecnego zarówno w przyrodzie, jak i w dziejach ludzkości. Przyznawał jednak, że znacznie trudniej określić go w tym drugim przypadku, ponieważ ruch indywidualistyczny jest silniejszy, zdeterminowany wolną wolą człowieka. Rzeczywistość składa się więc z będących w ciągłym konflikcie jednostek, a te z kolei składają się na wyższą jednostkę - naród. Każdy zaś naród, o ile dysponuje trwałym i odrębnym charakterem narodowym, pozostaje w konflikcie z innymi - a wyrazem tego konfliktu jest właśnie „Historia”. W ten sposób narody (Nationerne) poddane ciągłej zmienności dziejowej, zmierzają ku nieuniknionemu celowi, którym jest ostateczne urzeczywistnienie wolności. Czynnikiem wprowadzającym narody w ruch, zdaniem interpretującego schellingianizm Steffensa, jest idea (duch), czyli wyrażona w poezji, sztuce i filozofii - religia. Postulat religijności rozumiał jednak także po schellingiańsku: „Historia zaczyna się od Bogów. Za dziejami kryje się mitologia, która jest źródłem bytu, zaś wyrazem okresu boskiego jest najczystsza poezja i język"10.

${ }^{9}$ F. Rønning, N. F. S. Grundtvig. Et bidrag til skildring af dansk åndsliv i det 19. århundrede, København 1907-1914, s. 60-61.

10 J. Steenstrup, Historieskrivningen i Danmark i det 19. Aarhundrede, København 1889, s. $35-37$. 
Idąc za wskazówkami Steffensa, Duńczycy, a także Norwegowie, doszukiwali się w mitologii nordyckiej i w najdawniejszych dziejach Skandynawii źródeł i potwierdzenia wolności jako istoty narodowości.

Narodowa optyka historiografii skandynawskiej, tak ściśle związana z politycznymi i społecznymi przemianami w Skandynawii na początku XIX w., była swoistym miernikiem ewolucji świadomości narodowej w Danii, Szwecji i Norwegii. Nacjonalizm skandynawski można określić jako skierowany do wewnątrz, skupiający się na pielęgnacji własnych cech narodowych. Widoczne jest to szczególnie w przypadku Danii, która, zepchnięta do pozycji małego, prowincjonalnego państewka Europy, poszukiwała swej siły w wartościach narodowych. Historiografii duńskiej wyznaczono rolę pokrzepienia samopoczucia narodowego przez wydobycie z dziejów momentów wspaniałych i chwalebnych, ukazania okoliczności, w jakich mogły w przeszłości zaistnieć, a następnie dzięki tej wiedzy wskrzeszenie nowej, wspaniałej Danii. Od historyków Duńczycy domagali się recepty na choroby współczesności, na upadek monarchii duńskiej, utratę Norwegii i stale zagrożenie ze Wschodu i Południa. I historycy, wspomagani przez drugą „pocieszycielkę" narodu - literaturę romantyczną, „złoty wiek” dziejów odnaleźli w nordyckiej starożytności i w średniowieczu, w epoce wspólnoty nordyckiej i pełnej wolności, tzn. w okresie dominacji monarchii duńskiej. Wniosek nasuwał się sam - czynnikiem gwarantującym państwom skandynawskim odrodzenie i wyzwolenie spod obcych wpływów jest nordycka Jedność. I oto, zdając sobie sprawę ze swej zewnętrznej i wewnętrznej słabości, Duńczycy głosili, że narodowa wolność jest możliwa wyłącznie przez integrację nordycką.

„Nordyckość” usiłowano wyjaśnić różnicą między ludami germańskimi: północnogermańskimi, czyli nordyckimi, oraz południowogermańskimi, czyli niemieckimi ${ }^{11}$. Nie bacząc na wymogi obiektywizmu historycznego, starano się za wszelką cenę udowodnić odrębność Danii i całej Skandynawii, gdzie wolność, czyli nordycki duch narodowy, zachowały się w najczystszej postaci ${ }^{12}$. Wniosek ten nakazywał, w trosce o zachowanie czystości narodowej Skandynawów, odcięcie się od wszelkich obcych, także śródziemnomorskich i słowiańskich wpływów, których doszukiwano się również w narodowości niemieckiej. Za sprzeczny z ideologią nordycką uznano pangermanizm, który z „czystego ducha nordyckiego” wyciągał krańcowo odmienny wniosek. Ideolodzy niemieckiego ruchu zjednoczeniowego akcentowali znaczenie nordyckiego ducha narodowego jako platformy ideowej zjednoczenia wszystkich ludów germańskich,

${ }^{11}$ Ibidem.

12 „Nyt Aftenblad”, København, 25 IX 1824. 
niemieckich i skandynawskich w Wielką Germanię. Ponieważ postulat ten oznaczał dla Duńczyków po prostu wchłonięcie Danii przez Niemcy, a ponadto na wschodzie Europy rozwijał się, w ich rozumieniu równie groźny, panslawizm, skandynawizm wydawał się koniecznym antidotum ${ }^{13}$.

Pierwsze oznaki takiej wykładni skandynawizmu, wysuwającej na pierwszy plan elementy narodowościowe wraz z postulatem kształcenia świadomości narodowej i nordyckiej - panskandynawskiej zarysowały się w twórczości poetyckiej, jak zwykle najszybciej podchwytującej nowe idee. W poezji zadomowił się specyficzny „duch Północy”, uosabiający wspólnego dla wszystkich trzech narodowości ducha narodowego. Podobną myśl ogłosił Hans Christian Andersen w wierszu zaczynającym się od słów "Jesteśmy jednym ludem - nasze imię Skandynawowie" $(1839)^{14}$. Romantyczne przenikanie się świadomości narodowej i ponadnarodowej znalazło wyraz w teoriach Hansa Christiana Ørsteda, fizyka i przyrodnika, odkrywcy magnezu. Okazją stały się organizowane od 1839 r. kongresy przyrodników skandynawskich. Stosunek do owych zjazdów przedstawicieli poszczególnych narodów to także ocena romantycznego skandynawizmu. Dla Szwedów były one wyrazem oświeceniowych „wiecznych idei o nauce bez granic”, Norwegowie praktycznie potraktowali je jako forum wymiany doświadczeń, jedynie Duńczycy uznawali kongresy za wyraz zbliżenia narodowego, za pierwszy krok do zjednoczenia kultur, języków, nauki ${ }^{15}$.

Ogromne znaczenie dla przełamywania barier miała skandynawistyczna działalność kopenhaskich studentów, którzy dwukrotnie zorganizowali liczne zloty studenckie. W $1843 \mathrm{r}$. w zjeździe w Uppsali oprócz miejscowych wzięli udział studenci z Kopenhagi i Lund; z norweskiej Christianii nikt się nie pojawił. Dwa lata później, gdy w Kopenhadze ugoszczono żaków z Lund i Uppsali, z Christianii przybyło trzech odważnych. We wszystkich zlotach uczestniczyły setki studentów, w euforii namawiających do powrotu do dawnej wikińskiej wspólnoty. Symbolicznym przypieczętowaniem skandynawizmu studenckiego był udział w wojnie duńsko-pruskiej w latach 1848-1850 ochotników z uniwersytetów nordyckich, nawet z Christianii.

13 Briefwechsel der Gebrüder Grimm nordischen Gelehrten, wyd. E. Schmidt, Berlin 1885, s. 219, 230, 234. Zwróćmy w tym miejscu uwagę, że również w polskiej myśli filozoficzno-historycznej pojawia się w pierwszym okresie utraty niepodległości słowianofilska koncepcja Zoriana Dołęgi-Chodakowskiego, która również przypisywała wszelkie nieszczęścia narodowe obcym wpływom łacińskim.

14 „Vi er et folk - vort navn er Skandinaver”, H. C. Andersen og Norden, Dansk litteratur historie, red. C. Albeck, F. Billeskov Jansen, t. 1-2, København 1967, t. 2, s. 300.

15 „Den Constitutionelle”, Christiania, 16 VII 1840. 
Uprzedzenia Szwedów wobec Danii i Duńczyków udało się przełamać. W drugiej połowie XIX w., gdy ideę podchwycili monarchowie, inicjatywa ściślejszych związków wypłynęła właśnie ze strony Szwecji. Natomiast urazy, jakie żywili Norwegowie wobec swej dawnej metropolii (pisano o „zbrodniach popełnianych przez 400 lat unii”...) i wynikająca z nich izolacja, sprawiały, że obsesyjnie odrzucali oni wszelkie pomysły Duńczyków stworzenia „unii nordyckiej”. Skupieni na własnych problemach odbudowy norweskiej kultury narodowej po stuleciach duńskiej dominacji (choćby norweskiego języka literackiego), do idei nowej unii podchodzili nieufnie. Zwłaszcza że jako jedyny partner wśród trzech narodów nordyckich nie mieli własnego państwa. Dopiero w drugiej połowie XIX w., gdy skandynawizm przekształcił się w oficjalnie popieraną przez dwory i rządy nordyckie koncepcję, Norwegowie także ją sobie przyswoili. Oczywiście, nie w takim kształcie, w jakim lansowali ją romantycy: jako dość enigmatycznie określaną wspólnotę kultury i ducha nordyckiego, ale całkiem praktycznej bliskiej współpracy. Dowodem może być choćby zawarta w latach 1873-1875 unia monetarna, wprowadzająca we wszystkich państwach koronę i øre. Unia nordycka nigdy nie powstała, jednak jej idee nie tylko przetrwały w formie obecnej wspólnoty Norden wszystkich niepodległych państw, ale przede wszystkim w nowej mentalności i postrzeganiu nordyckich sąsiadów.

W XX w. trzy dalsze kraje nordyckie uzyskały niepodległość. W roku 1905 dzięki porozumieniu rozpadła się unia szwedzko-norweska, a obywateli norweskich zapytano nawet w referendum, czy popierają koncepcję Norwegii suwerennej. W kontekście wspomnianych uprzedzeń Norwegów wobec Danii, zwłaszcza po roku 1814, zaskakujący wydaje się wybór właśnie duńskiego księcia z królewskiej dynastii na pierwszego monarchę niepodległej Norwegii. Książę Karol, drugi w kolejności syn króla Danii Fryderyka VIII, jako monarcha Norwegii przyjął imię Haakona VII. Duński książę wydawał się mimo wszystko bliższy kulturowo Norwegom niż jakikolwiek inny kandydat do tronu.

Droga uzyskiwania niepodległości przez Islandię była długa; dopiero w 1918 r., w powojennej tendencji do samostanowienia narodów zgodnie z orędziem prezydenta Thomasa Woodrowa Wilsona, stała się suwerennym państwem w duńsko-islandzkiej unii personalnej. Porozumienie przewidywało przeprowadzenie po 25 latach referendum w sprawie pełnej niepodległości, do którego doszło w 1944 r. Fakt, że miało to miejsce podczas II wojny światowej i okupacji Danii, czasem skłania do błędnego wniosku, że Islandczycy skorzystali po prostu z okazji i zbuntowali się przeciwko duńskiej władzy. Cały proces odbył się jednak lege artis. Pozostałe dwa terytoria - Wyspy Owcze oraz Grenlandia - mają umocowany 
konstytucyjnie status autonomiczny w ramach monarchii duńskiej, choć Grenlandia jest od 1979 r. na najlepszej drodze do uzyskania pełnej niezależności. Trudno powiedzieć, że państwa regionu nagle połączyła przyjaźń, jednak zmiany kulturowe i w mentalności sprawiły, że wszystkie powyższe procesy przebiegały w sposób pokojowy, na drodze porozumienia i kompromisu. Nawet poważne spięcie między Danią i Norwegią na tle sporu o Grenlandię w latach trzydziestych zostało rozstrzygnięte przez międzynarodowy arbitraż.

W najgorszej sytuacji znalazła się Finlandia, zmuszona walczyć o niepodległość z siłą spoza nordyckiej rodziny - imperialną Rosją czasów caratu i rządów bolszewików. Droga do suwerennego państwa wiodła przez krwawą wojnę domową u schyłku I wojny światowej (1918), która w dużej mierze spowolniła bolszewicką ekspansję. Gdy dwadzieścia lat później Finlandia zmagała się w wojnie zimowej z Armią Czerwoną, w szeregach fińskiej armii walczyli ochotnicy z wszystkich krajów nordyckich.

II wojna światowa, a zwłaszcza diametralne zmiany w międzynarodowym powojennym statusie neutralnych dotąd państw nordyckich, zwracają uwagę na inne aspekty funkcjonowania wspólnoty nordyckiej. Przypomnijmy: podczas wojny Norwegia i Dania padły ofiarą niemieckiej inwazji, Finlandia zmagała się z ZSRR i walcząc o swe wschodnie terytoria zawarła sojusz z III Rzeszą, Islandię prewencyjnie zajęli alianci, Szwecja zaś pozostała neutralna, choć jej kontakty z Niemcami znacznie przekraczały granice neutralności. Doświadczenia wojenne nie pozostały bez wpływu na decyzje polityczne, które w pewnym zakresie wprowadziły do wspólnoty elementy ją dzielące. Wprawdzie powołana przez państwa regionu w 1953 r. Rada Nordycka tworzyła w istocie namiastkę unii (ekonomicznej, celnej, rynku pracy, kultury i nauki), ale jednocześnie Dania, Islandia i Norwegia przystąpiły do NATO; neutralne pozostały Szwecja i Finlandia. Pojawienie się tendencji integrujących w skali europejskiej dodatkowo zmieniło charakter wspólnoty nordyckiej: Dania, Szwecja oraz Finlandia związały się Unią Europejską, Norwegia i Islandia pozostały poza tymi procesami, choć ich związki z UE pozostają dość silne. W rezultacie rola współpracy państw regionu na płaszczyźnie Rady Nordyckiej znacznie osłabła.

Niemniej jednak rodzi się pytanie, dlaczego Islandia i Norwegia, odcinając się od pozostałych państw nordyckich, pozostają poza procesem integracji europejskiej. Dlaczego Norwegowie dwukrotnie w referendum odrzucili perspektywę przyłączenia się do Unii? Trudno sądzić, by jakąkolwiek rolę odgrywały w tym wypadku historyczne tradycje sprzed unii kalmarskiej, zwłaszcza że Islandia straciła swą suwerenność 150 lat przed jej zawarciem. Tym, co łączy oba te państwa, jest stosunkowo krótki 
„staż” niepodległości: Islandii od 1944 r. (autonomii od 1918), Norwegii od 1905 r. (autonomii od 1814). Szczególnie w dziewiętnastowiecznej Norwegii czytelny jest proces kształtowania się nowoczesnego narodu i świadomości narodowej, budowy lub - jak pisano już w pierwszej połowie XIX stulecia - odbudowy norweskiej kultury narodowej. Dla tak niedużego narodu, rekonstruującego swą narodową tożsamość po wiekach podległości, charakterystyczne było permanentne poczucie zagrożenia, które kazało odrzucać nawet po 100 latach od rozpadu unii z Danią wszelkie tradycje wspólnej niegdyś kultury. Na przełomie XIX i XX w. pisano wręcz o „dwóch norweskich plemionach" - jednym z szacunkiem odnoszącym się do duńsko-norweskich tradycji kulturowych, drugim z nienawiścią je odrzucającym. Zjawiskiem, które narodziło się w XIX stuleciu, był norweski nacjonalizm, zaprawiony strachem przed obcym. Gdy w roku 1972 przeprowadzono referendum dotyczące ewentualnego przystąpienia Norwegii do ówczesnej Europejskiej Wspólnoty Gospodarczej, narracja sporu została zdominowana przez hasła narodowe, wolnościowe i walki o zachowanie suwerenności Norwegii, tak przecież istotne w XIX stuleciu. W dniu głosowania, 25 września, przeciwnicy EWG zorganizowali akcję rozpalania staronordyckich varde (ildvarde), czyli stosów drewna w kamiennych kołach, które służyły za ostrzeżenie w przypadku niebezpieczeństwa lub wojny.

Negatywne postawy, stereotypy i uprzedzenia nie zniknęły więc całkiem ze współczesnej nordyckiej mentalności, w której ogromną rolę odegrały nacjonalizmy. W powyższych rozważaniach wskazuję jednak na niektóre zjawiska kulturowe i procesy w historii państw nordyckich, które umożliwiły im stopniowe odzyskiwanie utraconej państwowości bądź budowę całkiem nowych państw - w sposób pozwalający na uniknięcie rozlewu krwi. Jeśli z pewną dozą przesady założyć, że państwa regionu nordyckiego powstały na gruzach dawnej unii kalmarskiej, to wypracowana przez kilka stuleci kultura polityczna wspólnoty pozwoliła przekształcić negatywnie ocenianą historię unii w budującą świadomość i pamięć tradycję historyczną.

Biogram: Grażyna Szelągowska, dr hab., zatrudniona w Instytucie Historycznym Uniwersytetu Warszawskiego; od 2007 r. profesor UW. Kierunki badań: historia Skandynawii XVII-XX w., historia społeczna XIX i XX w., historia filmu oraz film w warsztacie historyka, dzieje luteranizmu nordyckiego; kontakt: g.szelagowska@uw.edu.pl. 